\title{
Cladistic reanalysis and historical biogeography of the genus Lycinus Thorell, 1894 (Araneae: Mygalomorphae: Nemesiidae) with description of two new species from western Argentina
}

\author{
Nelson Ferretti
}

\begin{abstract}
Background: The genus Lycinus includes ten species, one from Argentina, eight from Chile, and one from Brazil. Two new species from western Argentina are described, and some data on natural history are presented. A cladistic reanalysis with the newly described species is carried out, and a reconstruction of ancestral areas and primary Brooks Parsimony Analysis are performed. The origins of the main groups of Lycinus are also discussed in that light.

Results: Lycinus lagigliai sp. nov. and Lycinus nevadoensis sp. nov. are described. The distribution of these species comprised western Argentina at Mendoza province. The cladistic reanalysis showed Lycinus as monophyletic supported only by the synapomorphy of dorsal spines on male palpal tibia. The tree topology was as follows: (Lycinus epipiptus, Lycinus domeyko ((Lycinus longipes, L. nevadoensis sp. nov.) (Lycinus portoseguro, L. lagigliai sp. nov.)) (Lycinus caldera (Lycinus gajardoi, Lycinus choros)) (Lycinus tofo, Lycinus quilicura)). The biogeographical analysis showed a close relationship of the species from the Andean region and the South American Transition Zone. The reconstruction of ancestral areas recognized four vicariant nodes.
\end{abstract}

Conclusions: A hitherto two unknown Lycinus species are recognized and formally described, along with a cladistic reanalysis and historical biogeographical hypotheses.

Keywords: Andean; Mendoza; Spiders; Phylogeny; Taxonomy

\section{Background}

The Nemesiidae Simon, 1889 was raised to family status by Raven (1985) from the Nemesiae group proposed by Simon (1889). To date, the family comprises 366 species and 43 genera of medium-sized spiders that have a transverse fovea, eyes grouped on a tubercle, two to four short spinnerets, anterior tarsi without spines, tarsi III and IV with light or absent scopula, without claw tufts, and female's superior tarsal claws bipectinate with numerous teeth (Goloboff 1995; Montes de Oca and Pérez-Miles 2013). Goloboff (1995) revised the species of Nemesiidae from Peru, Chile, Argentina, and Uruguay since only a few contributions to the systematics of this family concluded (Indicatti and Lucas 2005; Indicatti

Correspondence: nferretti@conicet.gov.ar

Centro de Estudios Parasitológicos y de Vectores CEPAVE (CCT-CONICET-La Plata), Calle 2 N584, La Plata B1902CHX, Argentina et al. 2008; Lucas et al. 2008; Lucas and Indicatti 2010; Montes de Oca and Pérez-Miles 2013). Neotropical nemesiids usually live in silk tubes constructed under stones or logs or in burrows covered by a trapdoor (Capocasale and Pérez-Miles 1990; Goloboff 1995; Ferretti et al. 2011).

Recently, as the result of the examination of a lot of some mygalomorph spiders collected in Mendoza and deposited in the arachnological collection of the Instituto Argentino de Investigaciones de las Zonas Áridas (CAI), I found six mygalomorph species belonging to the Nemesiidae. The six species belong to the genera Chaco Tullgren, 1905, Diplothelopsis Tullgren, 1905, and Lycinus Thorell (1894), with the latter genus showing a remarkable predominance in abundance and diversity. Thus, the present study is focused on the genus Lycinus. 
Lycinus was established by Thorell (1894), with the type species, Lycinus longipes Thorell, 1984, based on a male from Córdoba, Argentina. Goloboff (1995) emended the diagnosis of the genus, mentioning that the 'only possible autapomorphy for the genus is the male bulb being coniform and gradually tapering to form the embolus. It can be quickly distinguished from Diplothelopsis Tullgren, 1905 by having the posterior median spinnerets present, and from Flamencopsis and Chilelopsis by the female patella IV having strong 1-1-1 prolateral spines'. The genus includes ten species, one from Argentina (L. longipes), eight from Chile, and one from Brazil (Goloboff 1995; Lucas and Indicatti 2010; Platnick 2014).

In this paper, I present the description of two new species of Lycinus: Lycinus lagigliai sp. nov. from Nacuñan, Santa Rosa, central-eastern Mendoza, Argentina, and Lycinus nevadoensis sp. nov. from Cerro Nevado, Malargüe, southwestern Mendoza, Argentina. Also, new distributional data is presented for L. longipes and for Lycinus epipiptus (Zapfe, 1963), confirming the presence of this species in Argentina. Moreover, I present a cladistic reanalysis of Lycinus with newly described species and show data on natural history for some of the mentioned species. Finally, a reconstruction of ancestral areas and primary Brooks Parsimony Analysis are performed together with discussion concerning the origin of the main groups of Lycinus.

\section{Methods}

The examined material is deposited in the arachnological collection of the Instituto Argentino de Investigaciones de las Zonas Áridas (CAI, Susana Lagos Silnik). Specimens were examined using an Olympus SZ stereomicroscope (Shinjuku, Tokyo, Japan). Spine notation follows Petrunkevitch (1925). Terminology of genitalia follows Goloboff (1995). All measurements are in millimeters and were taken with a millimetric ocular lens. The leg segment length was measured between joints in dorsal view. Total body length excluded chelicerae and spinnerets. Left male palpal bulb was removed from the cymbium and photographed in prolateral, retrolateral, and ventral views. Specimens were photographed using a SONY Hx200v camera (Minato, Tokyo, Japan) attached to a stereomicroscope. Female genitalia was dissected and cleared in concentrated lactic acid for 60 to $120 \mathrm{~min}$.

\section{Cladistic analysis}

I scored the newly described species (L. lagigliai sp. nov. and $L$. nevadoensis sp. nov.) and two recently described Lycinus portoseguro Lucas and Indicatti, 2010 and Lycinus choros Lucas and Indicatti, 2010 for 27 characters (Table 1) from Goloboff (1995), removing invariant characters and adding a new one (character 26). The ingroup comprised 12 taxa: L. longipes Thorell, 1894; Lycinus gajardoi (Mello-Leitão, 1940); Lycinus caldera Goloboff, 1995; Lycinus tofo Goloboff, 1995; L. frayjorge Goloboff, 1995; L. epipiptus (Zapfe, 1963); Lycinus domeyko Goloboff, 1995; Lycinus quilicura Goloboff, 1995; L. portoseguro Lucas and Indicatti, 2010; L. choros Lucas and Indicatti, 2010; L. lagigliai sp. nov., and L. nevadoensis sp. nov. The outgroup included the following: Chilelopsis calderoni Goloboff, 1995; Diplothelopsis bonariensis Mello-Leitão, 1938, and Chaco obscura Thorell, 1894. The outgroup taxa are considered close relatives of Lycinus (Goloboff, 1995). The tree was rooted using $C$. obscura. The data matrix was constructed using Nexus Data Editor ver 0.5.0 software (Page 2001). The cladistic analysis was carried out with the program TNT version 1.1 (Goloboff et al. 2003), using maximum parsimony as the optimality criterion. Tree searches were conducted using implicit enumeration and implied weighting (Goloboff 1993) with concavity indices $(K)$ ranging from 1 to 6 .

Characters (Table 1): (0) Sternum: 0, wide; 1, normal; 2, long. (1) Maxillary cuspules in females: 0 , few (0 to 10); 1 , medium (11 to 30); 2, many (over 30). (2) Maxillary cuspules in males: 0 , few (0 to 10); 1 , medium (11 to 30); 2 , many (more than 30). (3) Female tarsi: 0, rigid; 1, flexible. (4) Scopula IV: 0, absent/very light; 1, light; 2, dense. (5) Basal bothrial plate: 0 , convex; 1 , flattened and with deeper ridges. (6) Trichobothria on male cymbium: 0, 1:3 M; 1 , 1:2 B. (7) Preening combs: 0, absent; 1, present; 2, pseudocombs. (8) Dorsal spines on male palpal tibia: 0, absent; 1 , present. (9) Spines on male cymbium: 0, present; 1 , absent. (10) Proventral setae on male palpal tibia: 0 , weak; 1 , strong. (11) Dorsal spines on male tibia I: 0, absent; 1 , present. (12) Dorsal spines on male posterior tibia: 0 , few/ absent; 1, numerous. (13) Spines on male patella I: 0, 0 R; 1, 1-1 R. (14) Shield of setae on male tibia I: 0, absent; 1 , present. (15) Spines on male patellae I-II: 0, 0/1 P; 1, 1-1-1 P. (16) Male palpal tibia: 0, short; 1, long; 2, very long. (17) Male cymbium: 0 , normal; 1 , narrow, asymmetric, with posterior lobe longer. (18) Male cymbium: 0, normal; 1, large. (19) Setae on male cymbium: 0, thin, hairlike setae; 1, thickened setae. (20) Setae male cymbium: 0, directed forward; 1, directed backward. (21) Male bulb keels: 0, absent; 1 , parallel keels or ridges along embolus base; 2 , lateral keels or flanges. (22) Male bulb: 0, normal size; 1, large. (23) Male bulb shape: 0, piriform; 1, conical. (24) Male embolus: 0, short; 1, long; 2, very long. (25) Burrow entrance: 0 , open; 1 , hinged door; 2 , flap door; 3 , double flap; 4, stopper door. (26) Retrolateral megaspine on male tibia I: 0, absent; 1 , present.

\section{Biogeographical analysis}

During the past few years, event-based methods are increasingly being used in historical biogeographic studies, 
Table 1 Data matrix for the genus Lycinus and the outgroup

\begin{tabular}{|c|c|c|c|c|c|c|c|c|c|c|c|c|c|c|c|c|c|c|c|c|c|c|c|c|c|c|c|}
\hline & & & & & & & & & & & 1 & & & & & & & & & & 2 & & & & & & \\
\hline & 0 & 1 & 2 & 3 & 4 & 5 & 6 & 7 & 8 & 9 & 0 & 1 & 2 & 3 & 4 & 5 & 6 & 7 & 8 & 9 & 0 & 1 & 2 & 3 & 4 & 5 & 6 \\
\hline C. obscura & 1 & 1 & 1 & 1 & 1 & 0 & 0 & 0 & 0 & 1 & 0 & 0 & 0 & 0 & 0 & 0 & 1 & 0 & 0 & 0 & 0 & 1 & 0 & 1 & - & - & 0 \\
\hline D. bonariensis & 0 & 0 & 0 & 1 & 2 & 0 & 1 & 0 & 0 & 1 & 0 & 1 & 1 & 1 & 0 & 1 & 1 & 0 & 0 & 1 & 0 & 0 & 0 & 0 & 1 & - & 0 \\
\hline C. calderoni & 1 & 2 & 2 & 0 & 1 & 1 & 0 & 1 & 0 & 1 & 0 & 1 & 0 & 1 & 1 & 1 & 0 & 0 & 0 & 0 & 0 & 2 & 0 & 0 & 1 & 0 & 0 \\
\hline L. longipes & 0 & 0 & 0 & 0 & 2 & 0 & 1 & 0 & 1 & 1 & 0 & 1 & - & 1 & 0 & 1 & 1 & 0 & 0 & 1 & 0 & 1 & 0 & 1 & 0 & 2 & 0 \\
\hline L. gajardoi & 1 & 0 & 0 & 1 & 1 & - & 1 & 2 & 1 & 1 & 0 & 1 & 1 & 1 & 0 & 1 & 0 & 1 & 0 & 1 & 1 & 1 & 0 & 1 & 1 & 1 & 0 \\
\hline L. caldera & 1 & 2 & 1 & 1 & 2 & - & 1 & 0 & 1 & 1 & 0 & 1 & 1 & 1 & 0 & 1 & 0 & 0 & 1 & 1 & 1 & 1 & 0 & 1 & 0 & 1 & 0 \\
\hline L. tofo & 1 & 0 & 0 & 1 & 2 & - & 1 & 0 & 1 & 1 & 1 & 1 & 1 & 1 & 0 & 1 & 1 & 0 & 0 & 1 & 0 & 1 & 0 & 1 & 2 & 1 & 0 \\
\hline L. frayjorge & 1 & 1 & - & 1 & 2 & - & - & 0 & - & 1 & - & - & - & - & - & - & - & 0 & 0 & - & - & - & 0 & - & - & 1 & - \\
\hline L. epipiptus & 1 & 0 & 0 & 1 & 2 & - & 1 & 0 & 1 & 1 & 0 & 1 & 1 & 1 & 0 & 1 & 1 & 0 & 0 & 1 & 0 & 1 & 0 & 1 & 0 & 1 & 0 \\
\hline L. domeyko & 1 & - & 0 & 1 & 2 & - & 1 & 0 & 1 & 1 & 0 & 1 & 1 & 1 & 0 & 1 & 1 & 0 & 0 & 1 & 0 & 1 & 0 & 1 & 0 & 1 & 0 \\
\hline L. quilicura & 1 & - & 0 & 1 & 2 & - & 1 & 0 & 1 & 1 & 1 & 1 & 1 & 1 & 0 & 1 & 1 & 0 & 0 & 1 & 0 & 1 & 0 & 1 & 2 & 1 & 0 \\
\hline L. portoseguro & 1 & 2 & 2 & 0 & 0 & - & - & 2 & 1 & 1 & 0 & 0 & 1 & 1 & 0 & 1 & 1 & 0 & 0 & - & 0 & 1 & 0 & 1 & 0 & - & 1 \\
\hline L. choros & 1 & - & 0 & - & 1 & - & - & 0 & 1 & 1 & 0 & 1 & 1 & 1 & 0 & 1 & 0 & 0 & 0 & 1 & 1 & 1 & 0 & 1 & 1 & - & 0 \\
\hline L. lagigliai sp. nov. & 1 & 0 & 0 & 0 & 2 & - & 1 & 2 & 1 & 1 & 0 & 1 & 1 & 1 & 0 & 1 & 1 & 0 & 0 & 1 & 0 & 1 & 0 & 1 & 1 & 2 & 0 \\
\hline L. nevadoensis sp. nov. & 0 & - & 0 & - & 2 & - & 1 & 0 & 1 & 1 & 0 & 1 & 1 & 1 & 0 & 1 & 1 & 0 & 0 & 1 & 0 & 1 & 0 & 1 & 0 & 2 & 0 \\
\hline
\end{tabular}

due to the noticeable increase in phylogenetic studies (Donato 2006; Guo and Wang 2007; Antonelli et al. 2010; Ferretti et al. 2012). These methods propose explicit models for the processes that affect the geographic distribution of living organisms (Crisci et al. 2003). To reconstruct ancestral distributions of Lycinus, the RASP 2.0 (Reconstruct Ancestral State in Phylogenies) software was used. This program determines statistical support for ancestral range reconstructions using the RASP value, and frequencies at a node are averaged over all trees with each alternative ancestral range weighted (Yu et al. 2010). In order to obtain a better resolution for ancestral reconstruction, RASP only accepts free polytomies trees; thus, the solved part of the cladogram was used. Distributional data of the genus Lycinus were taken from Goloboff (1995) and the records obtained in the present study. Four main areas defined in previous biogeographic schemes (Morrone 2006, 2014) were considered in the analysis. The following areas were used: Coquimbo (A) and Santiago (B) from the Andean region, Brazilian Atlantic Forest province (D) from the Neotropical region, and Monte province (C) from the South American Transition Zone. L. longipes has a wide distribution in western Argentina, occupying five biogeographic provinces; thus, for the purposes of RASP (to avoid many areas with only one species), we only consider the occupancy of the Monte province, where this species shows more abundance.

Primary Brooks Parsimony Analysis (BPA) was carried out in order to reconstruct area relationships according to the resolved phylogeny of the genus Lycinus (Brooks et al. 2001). The biogeographical analysis used distributional data of Lycinus reconciled to the phylogenetic hypothesis obtained in this study. For that, an individual area cladogram for the analyzed taxa constructed by replacing species names in the phylogeny with the areas where they occur was obtained. Internal and terminal nodes were numbered for later incorporation in the data matrix and were analyzed using a parsimony algorithm with TNT 1.1 (Goloboff et al. 2003). A hypothetical area with the absence of all taxa was added to the data matrix to root the cladogram. From this procedure, the area cladogram obtained was established as a general pattern of area relationships (Brooks et al. 2001).

\section{Results and discussion Cladistics}

The phylogenetic analysis using implied weighting and implicit enumeration resulted in a single tree (Figure 1) with $K$ values from 1 to 6 (51 steps, consistency index $(C I)=0.62$, retention index $(R I)=0.56, K=1$, fit $=5.50$, $K=6$, fit $=2.03$ ). The tree did not show the genus Lycinus as monophyletic and the lack of resolution is caused only by Lycinus frayjorge (a species for which males are unknown), and for which the only two synapomorphic characters for Lycinus had to be scored as missing entries. In the tree, Lycinus is paraphyletic by virtue of placing $L$. frayjorge as the sister group of $D$. bonariensis plus the rest of Lycinus. Goloboff (1995) obtained a tree where $L$. frayjorge is placed as a sister group of L. caldera, and as the author stated, it seems much more likely that the species actually belongs to the same group as L. gajardoi and L. caldera, also found in northern Chile'. Therefore, a single tree with the same topology 


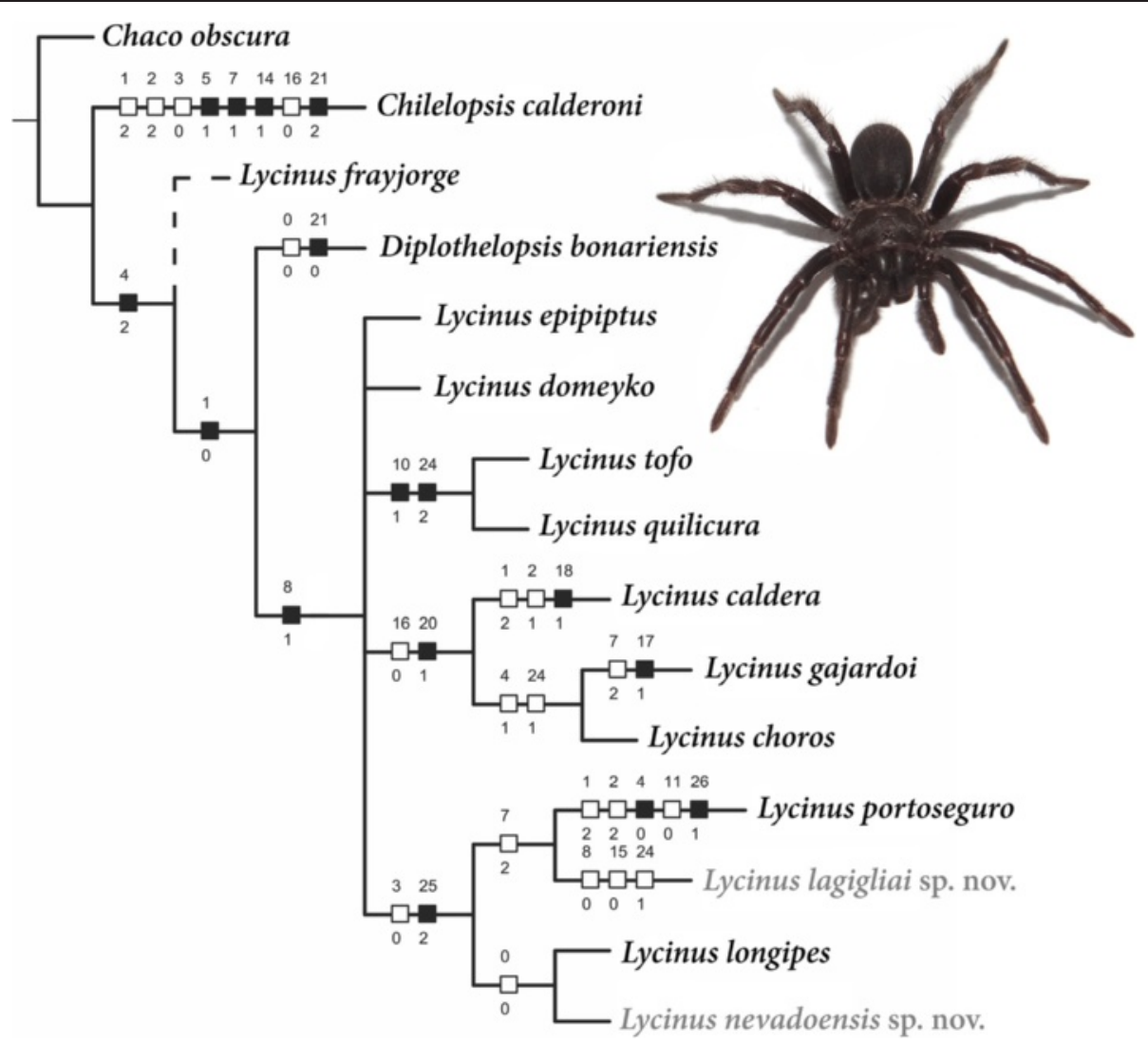

Figure 1 Results from cladistic analysis. Most parsimonious tree obtained using implied weighting (51 steps, $\mathrm{Cl}=0.62, \mathrm{Rl}=0.56, \mathrm{~K}=1$, fit $=5.50$, $K=6$, fit $=2.03$ ).

was obtained by physically excluding $L$. frayjorge from the matrix in which Lycinus was recovered as monophyletic. The monophyly of the genus Lycinus was supported only by the synapomorphy of dorsal spines on male palpal tibia. Although Goloboff (1995) proposed as an additional synapomorphy of Lycinus the coniform male palpal bulb, in this analysis, the character was shared by C. obscura. L. gajardoi and L. choros share the light scopula on metatarsus IV and male embolus long; the sister group of these two species is L. caldera, which shares the short male palpal tibia and the posteriorly directed cymbial setae. The group formed by $L$. quilicura and $L$. tofo share the strong proventral setae on male palpal tibia and the male embolus being long. The relationships found and the characters supporting are the same as those found by Goloboff (1995). Otherwise, the newly included $L$. portoseguro and $L$. lagigliai sp. nov. are sister groups supported by the presence of pseudocombs. L. longipes and L. nevadoensis sp. nov. (supported by the presence of a wide sternum) are the sister groups of $L$. portoseguro and L. lagigliai based on the rigid female tarsi and the construction of a burrow with a flap door. The previous analysis of Goloboff (1995) did not show a resolved position for $L$. longipes.
Taxonomy

Nemesiidae Simon, 1889

Lycinus Thorell, 1894

Diagnosis: See Goloboff (1995)

\section{L. lagigliai sp. nov.}

Type material Holotype $\hat{\sigma}$ (CAI 3375) from Argentina, Mendoza, Santa Rosa department, Nacuñan, 20 October to 22 November 1997. Paratype of (CAI 3495) from Argentina, Santa Rosa department, Ñacuñan, 34 $2^{\prime} 47.2^{\prime \prime}$ S, 6754' $26^{\prime \prime} \mathrm{W}, 547$ meters above sea level (m.a.s.l.), 12 February 2013, N. Ferretti leg.

Etymology Named in honor of Humberto Antonio Lagiglia (San Rafael, Mendoza, 1938 to 2009), an outstanding Argentinean anthropologist, archeologist, and naturalist born in San Rafael, Mendoza. This researcher contributed to the knowledge of the Ansilta culture and also was the founder and first director of the Museum of Natural History of San Rafael.

Diagnosis Males and females of L. lagigliai sp. nov. can be distinguished from those of their congeners by the 
color pattern, the shape of the palpal bulb, and the shape of the spermathecae. It resembles $L$. longipes by the general aspect of the bulb, but differs from it by the longer embolus with five low diagonal keels (instead of two strong keels); it also differs by the smaller body size, the sternum longer than wide, and metatarsi III and IV scopulated.

\section{Description Male (CAI 3375)}

Color in alcohol: entire spider brownish, carapace covered with many whitish hairs, abdomen lighter (Figure 2E,G). Total length 18.7. Carapace 9.3 long, 7.2 wide, fovea deep, procurve, 1.02 wide (Figure 2E). Clypeus narrow, 0.4. Anterior and posterior eye row procurve. Eyes sizes and interdistances: AME 0.37, ALE 0.31, PME 0.10, PLE 0.19, AME-AME 0.22, AME-ALE 0.09, PME-PME 0.82, PME-PLE 0.03, ALE-PLE 0.15. Eye quadrangle 0.9 long, 1.4 wide. Basal segment of chelicerae with five teeth, each in one row on promargin, with nine basal smaller teeth. Rastellum very weak. Intercheliceral tumescence large, rounded, pale yellow, with short thin setae. Labium 0.8 long, 1.1 wide. Labium and endites without cuspules. Sternum oval, slightly longer than wide, 4.5 long, 3.8 wide (Figure 2F). Six sternal sigilla, all away from margin by one length, posterior pair half of the size of anterior pair. Legs measurements are given in Table 2. Leg formula 4-3-1-2. Spination: tarsi I-IV and femur of palp: 0. Palp: patella $1 \mathrm{R}$; tibia 1 1-1-2 P. Legs: I: femur 1-1-1 D, 1-1 P; patella 1 P, $1 \mathrm{R}$; tibia 1-1D, $1 \mathrm{R}, 1-1-1 \mathrm{P}, 1 \mathrm{~V}$; metatarsus $1-1 \mathrm{~V}, 1-1-1 \mathrm{P}$, 1-1-1 R, 2-1-1-1-2 D. II: femur 2-2-2 D, 1-1 P; patella $1 \mathrm{P}$; tibia 1-2 V, 1-1-1 R, 1-1-1-1 P, 1-1-1 D; metatarsus 1-1-2-1-1 D, 1-1 P, 1-1-1-1 R, 1-1-2-2 V. III: femur 1-21-1 D, 1-1 P; patella $1 \mathrm{R}, 1-1-1 \mathrm{P}$; tibia 2-2-2-1 D, 1-1-1 P, 1-1-2 R, 2-1 V; metatarsus 1-1-3 V, 1-1-1 R, 1-1-2-11-2 P, 1-1-1-1 D. IV: femur 1-1-1-1-1 D, 1-1 P; patella 1-1-1 P, 1 R; tibia 1-1-1 D, 2-1-2-1 P, 1-1-1 R, 1-1-1 V; metatarsus 2-1-1 D, 1-1-1-3-2-1 P, 1-1-1-2 R, 1-1-2-2 V. Pseudopreening combs absent. Tarsi I-IV flexible. Scopulae on tarsi I-III full and entire, IV fully scopulated divided by a row of two setae. Scopulae entire on all metatarsi, I present on $1 / 2$, II on $1 / 3$, III on $1 / 4$, IV on $1 / 2$. Superior tarsal claws with two rows each of 9 to 11 teeth on all tarsi. Third claw absent on all tarsi. Four spinnerets, PLS three-segmented: basal, median, and apical (digitiform short) segments 1.7, 1.03, and 0.45 long, respectively. Cymbial setae long and apically directed (Figure 2D). Palp with coniform bulb gradually tapering to form embolus and with five very low diagonal keels (Figure 2A,B,C).

Female (CAI 3495)

Coloration pattern in vivo: carapace, coxae, and trochanters light brown with pinkish hairs, abdomen and legs dark with lighter color in metatarsus and tarsus

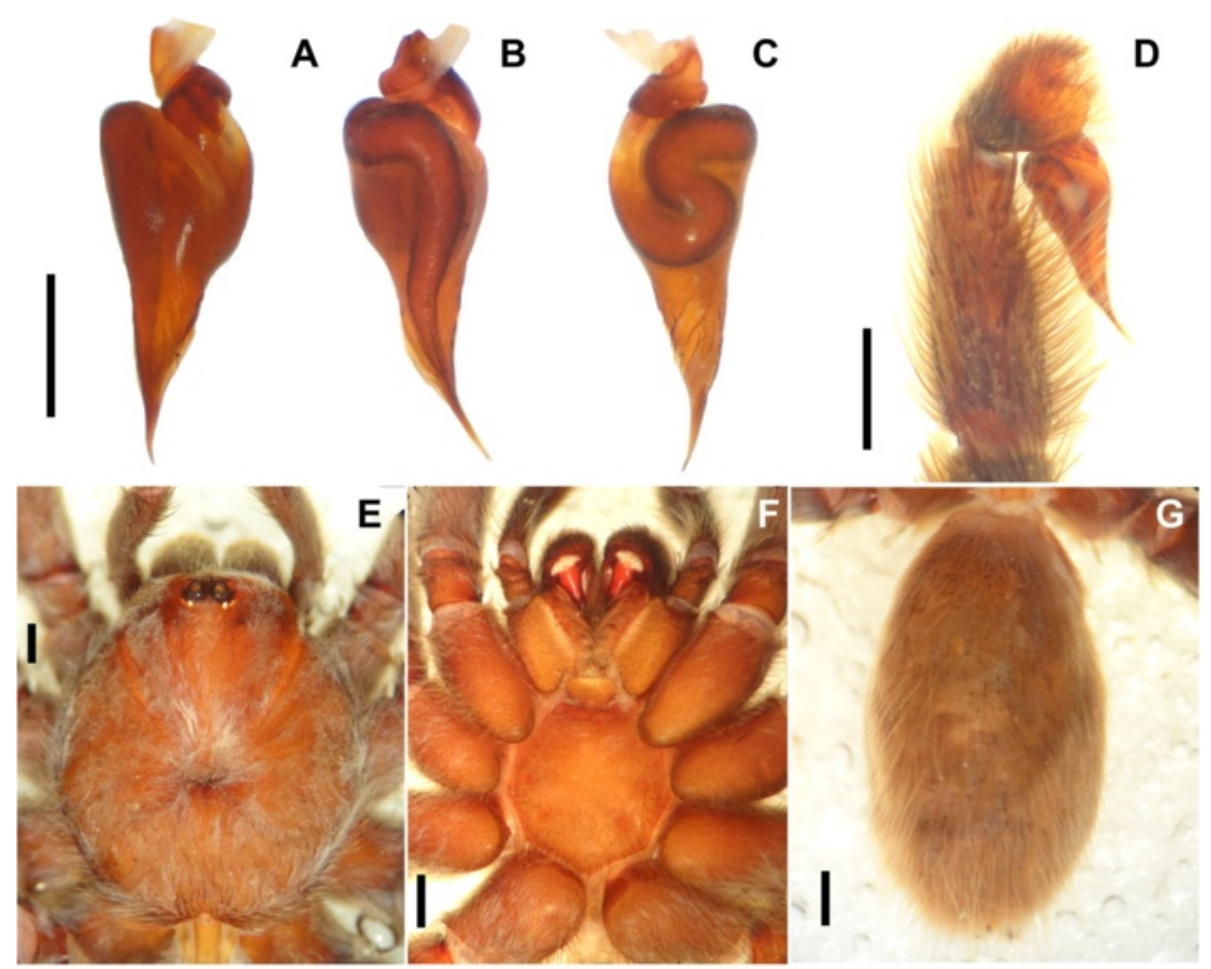

Figure 2 Lycinus lagigliai sp. nov., holotype male (CAI 3375). (A-C) Left palpal bulb: (A) prolateral, (B) ventral, (C) retrolateral. (D) Palpal tibia, retrolateral view. (E) Carapace, dorsal view. (F) Sternum, ventral view. (G) Abdomen, dorsal view. Scale bars = $1 \mathrm{~mm}$. 
Table 2 Lycinus lagigliai sp. nov., length of leg and palpal segments of male

\begin{tabular}{llllll}
\hline & I & II & III & IV & Palp \\
\hline Femur & 8.7 & 10.3 & 9.6 & 11.0 & 4.3 \\
Patella & 3.9 & 4.0 & 5.3 & 5.0 & 2.2 \\
Tibia & 7.3 & 4.5 & 6.3 & 8.8 & 3.0 \\
Metatarsus & 10.1 & 9.3 & 11.8 & 14.5 & - \\
Tarsus & 6.6 & 6.5 & 7.5 & 8.3 & 1.0 \\
Total & 36.6 & 34.6 & 40.5 & 47.6 & 10.5 \\
\hline
\end{tabular}

(Figure 3B). Color in alcohol: blackish with carapace lighter. Total length 16.3. Carapace 7.1 long, 6.1 wide, fovea deep, slightly procurve, 1.1 wide (Figure 3A). Clypeus narrow, 0.2. Anterior eye row procurve, posterior slightly procurve. Eyes sizes and interdistances: AME 0.29, ALE 0.16, PME 0.14, PLE 0.17, AME-AME 0.16, AME-ALE 0.07, PME-PME 0.55, PME-PLE 0.05, ALEPLE 0.24. Eye quadrangle 0.8 long, 1.1 wide. Basal segment of chelicerae with five teeth in one row on promargin, with ten basal smaller teeth. Rastellum strong formed by numerous small, short cusps. Intercheliceral tumescence absent. Labium 0.4 long, 1.2 wide. Labium without cuspules, endites with three and one cuspules, respectively. Sternum oval, longer than wide, 3.8 long, 3.5 wide (Figure 3C). Six sternal sigilla, all away from margin by one length, posterior pair half of size of anterior pair. Legs measurements are given in Table 3. Leg formula 4-3-2-1. Spination: tarsi I-IV: 0. Palp: femur 1 P; patella 1-1-1 P, $1 \mathrm{R}$; tibia 1-1-1 P, 1-3 V, tarsus $1 \mathrm{R}, 1-$ $1 \mathrm{~V}$. Legs: I: femur $1 \mathrm{D}, 1-1 \mathrm{P}$; patella 1-1 P; tibia 12 V, 1-1 P; metatarsus 1-1-2 V. II: femur 1-1-1 P; patella $1 \mathrm{P}$; tibia $1 \mathrm{P}, 1 \mathrm{~V}$; metatarsus 1-1-1-2 V. III: femur 1-1-1 R, 1-1-1-2-1 P; patella 1-1-1 P, 1 R; tibia 1-1-1 R, 1-1-22-2 P, 1-1-2 V; metatarsus 1-1-1 D, 1-1-1-1-1-2 P, 1-1-22 V, 1-1-1-1 R. IV: femur 1-1 R, 1-1-1-2 P, patella 1-1-1 P; tibia 1-1-2 V, 1 P, 1-1-1 R; metatarsus 1-1-1-1-1 P, 11-1-1 R, 1-1-2-1-1-2 V. Pseudopreening comb on metatarsus IV. Scopulae on tarsi I-IV full. Scopulae on tarsus I divided by row of two setae, on II and III divided by row of four setae, on IV divided by row of four long and strong setae, basal and apical scopulae divided by many rows of setae. Scopulae entire on metatarsi I, II, and IV, I present on $3 / 4$, II on $2 / 3$, III on $1 / 2$ divided by a line of setae, IV on $2 / 3$. Superior tarsal claws with two rows each of 7 to 13 teeth on all tarsi. Third claw absent on all tarsi. Four spinnerets, PLS three-segmented: basal, median, and apical (digitiform short) segments 0.5, 0.6, and 0.4 long, respectively. Genitalia with two long thin and straight copulation ducts and oval-shaped spermathecae (Figure 3D).

Other materials examined Argentina, Mendoza, Santa Rosa department, Nacunán, $34^{\circ} 2^{\prime} 40.6^{\prime \prime} S, 67^{\circ} 54^{\prime} 26^{\prime \prime} \mathrm{W}$, 540 m.a.s.l., 10 February 2013, N. Ferretti leg., 1 juvenile (CAI 3496); Santa Rosa department, Ñacuñán, 20 October to 22 November 1997, 3ð (CAI 3376, 3377, 3378).

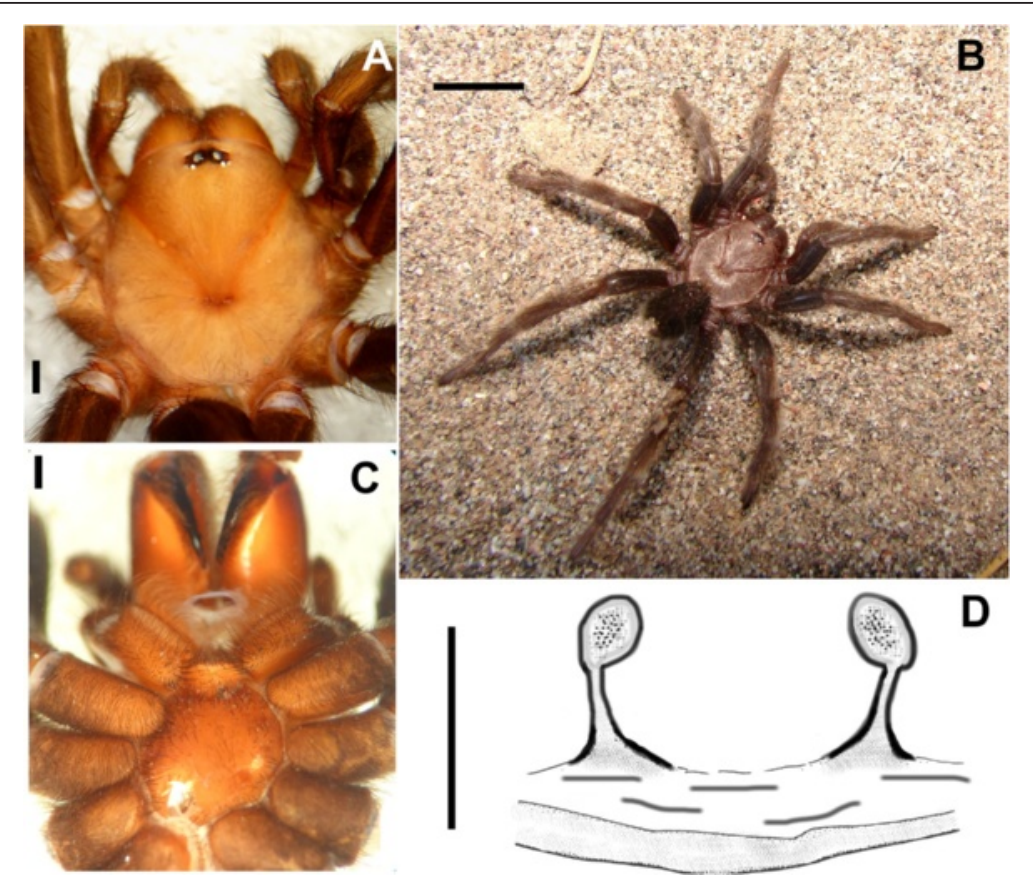

Figure 3 Lycinus lagigliai sp. nov., paratype female (CAI 3495). (A) Carapace, dorsal view. (B) Female live habitus. (C) Sternum, ventral view. (D) Spermathecae, dorsal view. Scale bars (A, C, and $\mathbf{D})=1 \mathrm{~mm}$. Scale bar $(B)=1 \mathrm{~cm}$. 
Table 3 Lycinus lagigliai sp. nov., length of leg and palpal segments of female

\begin{tabular}{llllll}
\hline & I & II & III & IV & Palp \\
\hline Femur & 5.8 & 5.4 & 5.8 & 6.7 & 2.8 \\
Patella & 2.4 & 3.3 & 2.7 & 3.9 & 1.9 \\
Tibia & 3.7 & 4.0 & 3.7 & 5.7 & 3.1 \\
Metatarsus & 4.2 & 4.5 & 5.9 & 9.2 & - \\
Tarsus & 3.0 & 3.1 & 4.0 & 5.0 & 2.2 \\
Total & 19.1 & 20.3 & 22.1 & 30.5 & 10.0 \\
\hline
\end{tabular}

Distribution and ecological notes Known only from the type locality, Biosphere Reserve of Nacuñán, Santa Rosa department, Mendoza (Figure 4). The reserve is located in the lowland Monte Desert of northwestern Argentina that harbors a significant amount of the biotic diversity, landforms, and disturbance regimes of the arid lands of South America (Ojeda et al. 1998). The characteristic habitat (Figure 5A) where L. lagigliai sp. nov. was found comprised shrubby steppe and 'matorral' dominated by Prosopis flexuosa, Geoffroea decorticans, Larrea divaricata, and Ligaria cuneifolia; arboreal woodland with $P$. flexuosa; shrubby woodland dominated by $L$. divaricata, Atriplex lampa, Verbena aspera, Lycium chilensis, Atamisquea enarginata, and Ephedra triandra; and herbaceous woodland characterized by Pappophorum caespitosum, Digitaria californica, and Setaria leucopila (Ojeda et al. 1998). Spiders were active at night, even one was found preying on a juvenile scorpion about $50 \mathrm{~cm}$ away from the burrow entrance and when disturbed quickly returned to the burrow (Figure 5B). During observations at night, I saw that the burrows are closed by means of a door, without hinge, which lies over the burrow mouth during day (Figure 5C) but, when opened, spiders leave the door by the side of the burrow, facing downward (Figure 5D). When disturbed, they quickly hold the door with the two first pair of legs and covered the burrow entrance. The burrow resembles that of L. longipes, but in L. lagigliai $\mathrm{sp.}$ nov., it seems to be unstable with little silk cemented to the walls and when touched quickly collapsed. In this habitat, specimens of Diplothelopsis ornata Tullgren, 1905 (Nemesiidae), Actinopus sp. (Actinopodidae), and Grammostola inermis Mello-Leitão, 1941 and Catumiri argentinense (Mello-Leitão, 1941), both from the Theraphosidae, were also found.

\section{L. nevadoensis sp. nov.}

Type material Holotype $\delta$ from Argentina, Mendoza, Malargüe department, Cerro Nevado, 35 $36^{\prime} 47.58^{\prime \prime} \mathrm{S}, 68^{\circ}$ 31'39.6"W, 2,610 m, 8/17 February 2006, G. Debandi \& E. Ruiz legs (CAI 3320). Paratypes: $2 \hat{\jmath}$, same data as holotype (CAI 3321, 3322).

Etymology The name 'nevadoensis' refers to the 'Cordón del Nevado' in Mendoza (Argentina), where the species was found.

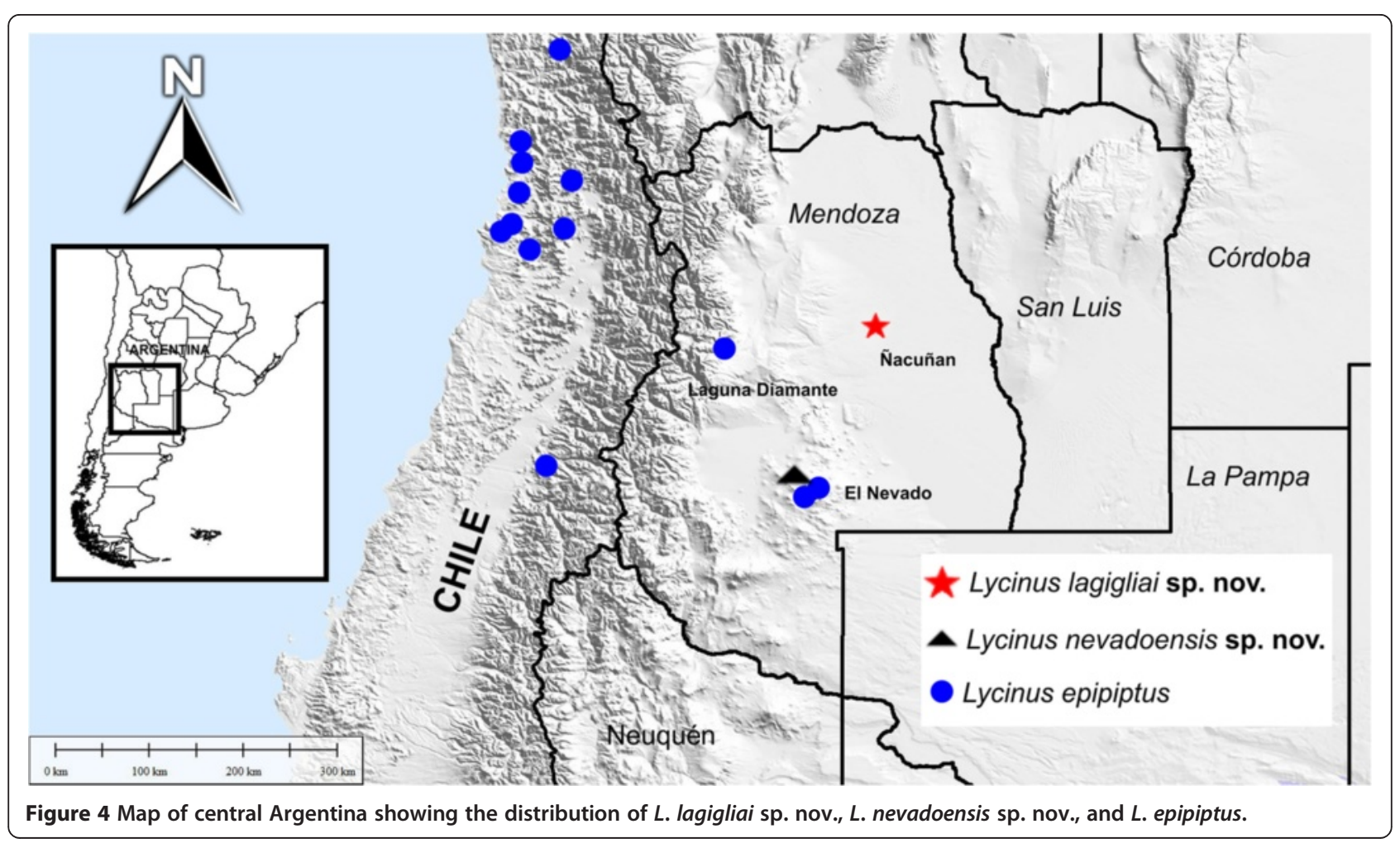




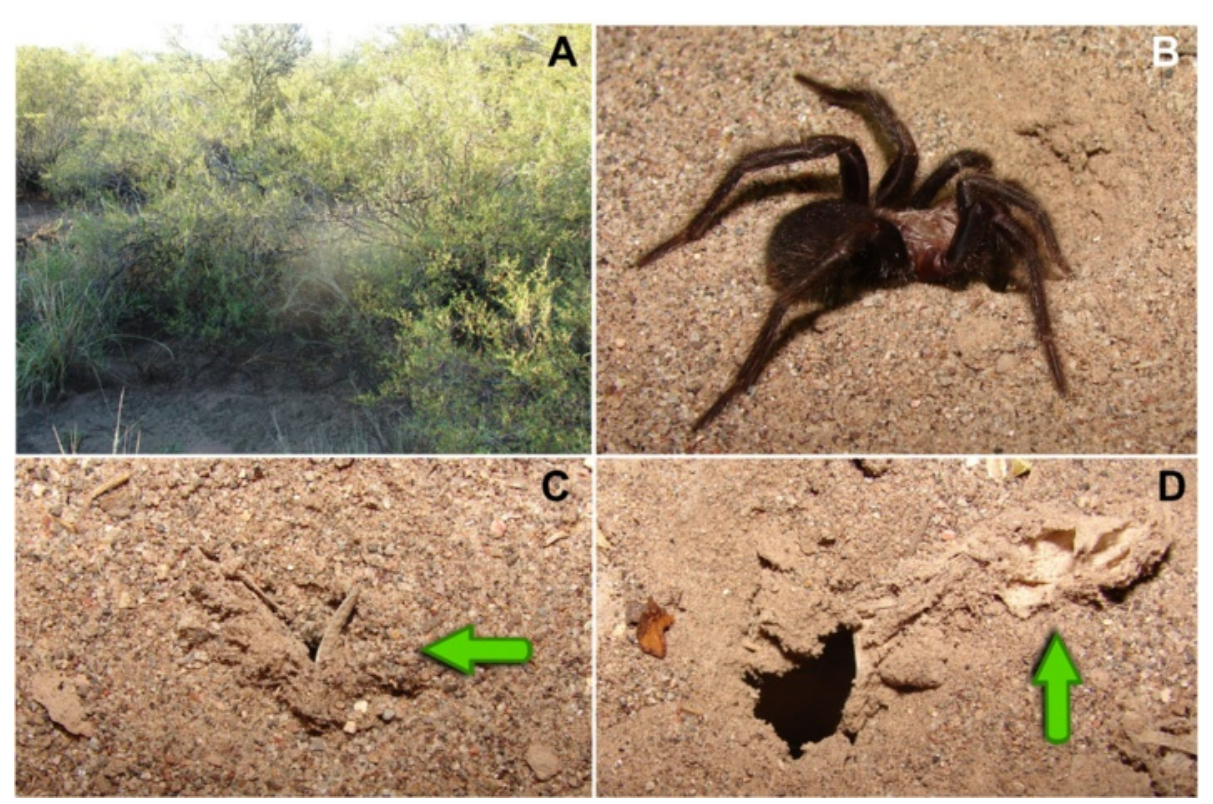

Figure 5 Natural history of L. lagigliai sp. nov. (A) Habitat characteristics where the species occur. (B) Juvenile returning to its burrow. (C) Female burrow with flap door closed. (D) Female burrow with opened flap door. Green arrows indicate the flap door.

Diagnosis Males of L. nevadoensis sp. nov. differ from those of the remaining species of the genus by the shape of the bulb and by the presence of spines on tarsi III and IV. They resemble $L$. domeyko in the body size and the palpal tarsus having thickened setae directed apically, but differ from it by the shape of the bulb, the absence of maxillary cuspules, and the scopula on tarsus IV being well developed. They resemble $L$. epipiptus by the light color and the patterned abdomen (Figures 6A,B,C and 7D), but in L. nevadoensis sp. nov., the abdomen is brownish with about six dark transverse lines (Figure 6B,C) (the abdomen of L. epipiptus is dark with lighter transverse lines).

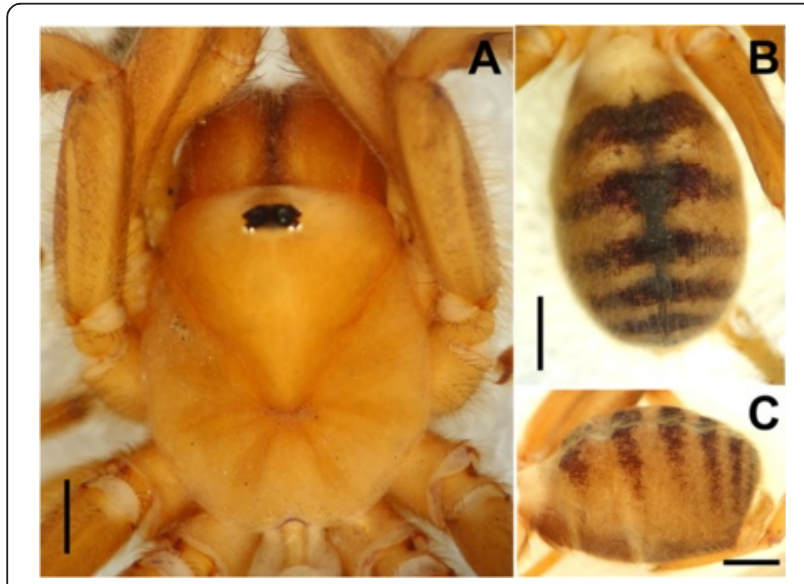

Figure 6 Lycinus nevadoensis sp. nov., juvenile (CAI 3353). (A) Carapace, dorsal view. (B) Abdomen, dorsal view. (C) Abdomen, lateral view.

\section{Description Male (CAI 3320)}

Color pattern in alcohol: entire spider brownish, carapace lighter, abdomen with clear-cut chevron occluded by hairs (Figure $8 \mathrm{E}, \mathrm{G}$ ). Total length 12.3. Carapace 6.7 long, 5.7 wide, fovea deep, slightly procurve, 0.9 wide. Clypeus narrow, 0.2. Anterior and posterior eye rows procurved. Eyes sizes and interdistances: AME 0.25, ALE 0.13, PME 0.07, PLE 0.09, AME-AME 0.20, AMEALE 0.07, PME-PME 0.51, PME-PLE 0.02, ALE-PLE 0.07. Eye quadrangle 0.6 long, 0.9 wide. Basal segment of chelicerae with five teeth, each in one row on promargin, with 11 basal smaller teeth. Rastellum weak with thick setae. Intercheliceral tumescence large, rounded, pale yellow, asetose. Labium 0.4 long, 0.9 wide. Labium and endites without cuspules. Sternum oval, wider than long, 1.9 long, 2.7 wide (Figure 8F). Six small sternal sigilla, all away from margin by one length. Measurements are given in Table 4. Leg formula 4-3-1-2. Spination: tarsi III: 0. Palp: femur $1 \mathrm{P}$; patella 1-1 P; tibia $1 \mathrm{R}, 2-1-1-2 \mathrm{D}$, 1-2-1-1 P, 1-1 V. Legs: I: femur 1-2-1-2 D, 1-1-1-1 P, 1 R; patella 1-1-1 P, $1 \mathrm{R}$; tibia 2-1-1 D, 2-1-1-2 R, 2-2-2 P, 2-2-1-2 V; metatarsus 1-1-1 V, 1-2-2-2-1 P, 1-1 R, 1-11-1-2 D. II: femur 2-1-1-2-1 D, 1-1-1 P, 1-1-1 R; patella 1-1-1 P, 1 R; tibia 1-2-2-2 V, 1-1-1 R, 1-2-1 P, 1-1-2 D; metatarsus 2-2 D, 2-1-2-2-1-1 P, 1-1-1-1 R, 2-1-1-1-2 V. III: femur 1-1-1-1 D, 1-1 P, 1-1-1-1 R; patella 1-1 R, 11-1 P; tibia 1-2-2-2 D, 2-2-2 P, 2-2-1 R, 1-1-1-1-1-2 V; metatarsus 2-2-1-1-2 V, 1-1-2-1-1 R, 2-1-2-1-2-2 P, 1-21-1-1 D; tarsus 1 D, 1 R, 1 P. IV: femur 1-1-1- P, 1-1-1-1 R, 1-1-1-1 D; patella 1-1-1 P, 1 R; tibia 2-2-2-2-1 D, 2-22-1 P, 2-1-1 R, 2-2-2 V; metatarsus 2-1-2-2 D, 1-1-1-1-2- 


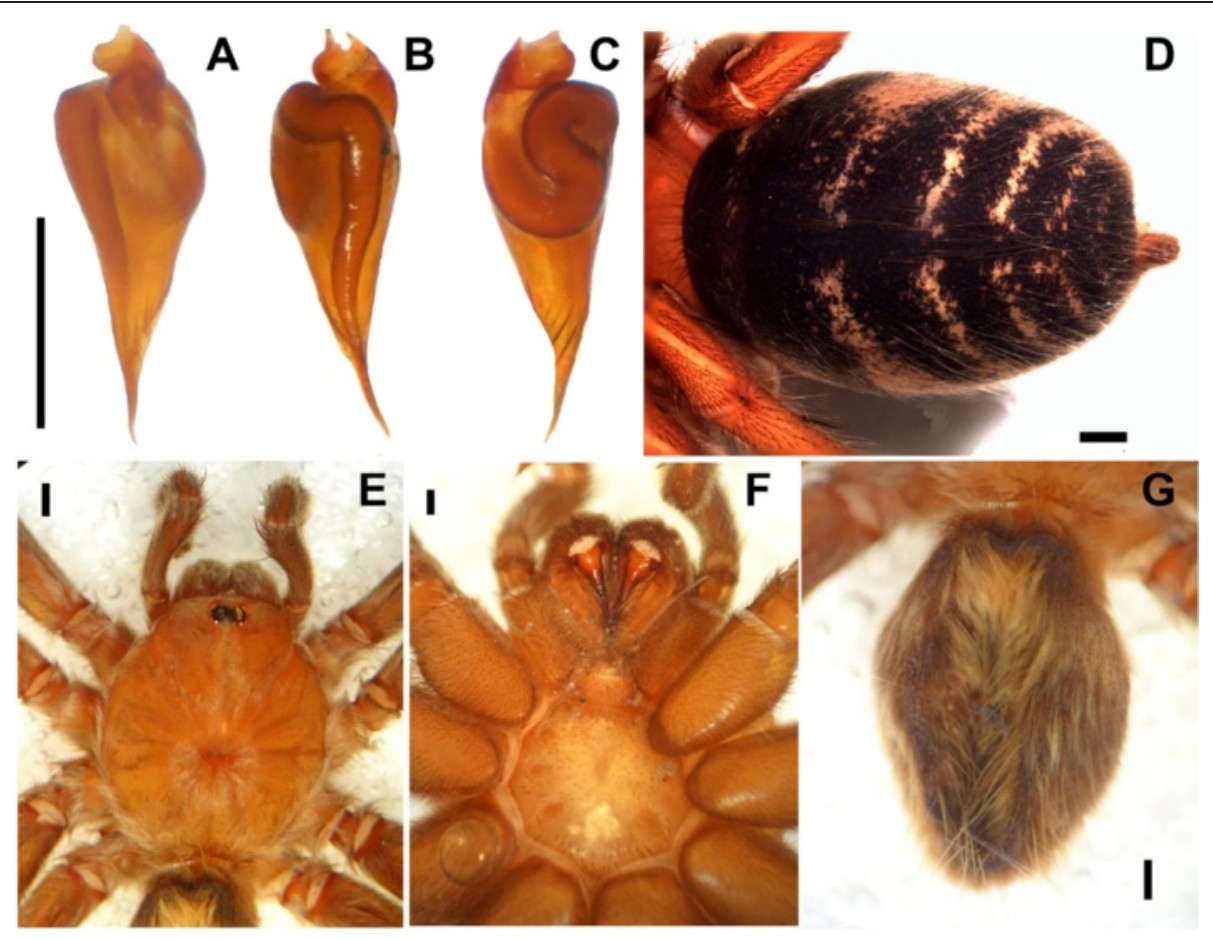

Figure 7 Lycinus epipiptus. (A-C, E-G) Male (CAI 3277). (D) Female (MACN-Ar). (A) Left palpal bulb, prolateral. (B) Left palpal bulb, ventral. (C) Left palpal bulb, retrolateral. (D) Abdomen, dorsal view. (E) Carapace, dorsal view. (F) Sternum, ventral view. (G) Abdomen, dorsal view. Scale bars $=1 \mathrm{~mm}$.

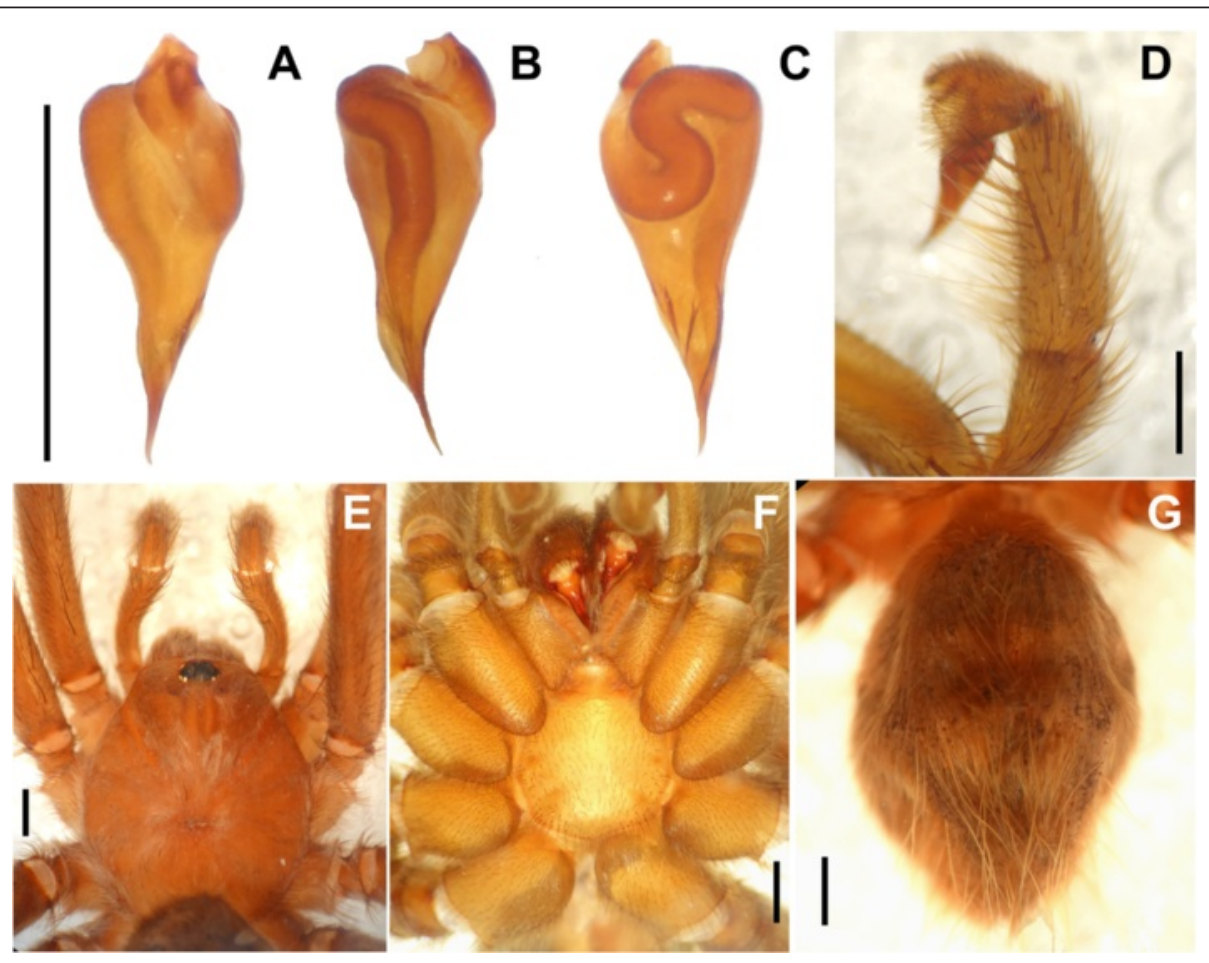

Figure 8 Lycinus nevadoensis sp. nov., holotype male (CAI 3320). (A-C) Left palpal bulb: (A) prolateral, (B) ventral, (C) retrolateral. (D) Palpal tibia, retrolateral view. (E) Carapace, dorsal view. (F) Sternum, ventral view. (G) Abdomen, dorsal view. Scale bars =1 mm. 
Table 4 Lycinus nevadoensis sp. nov., length of leg and palpal segments of male

\begin{tabular}{llllll}
\hline & I & II & III & IV & Palp \\
\hline Femur & 6.8 & 7.1 & 6.3 & 7.4 & 3.1 \\
Patella & 3.5 & 3.4 & 3.1 & 3.0 & 1.6 \\
Tibia & 5.1 & 4.5 & 4.9 & 5.4 & 2.2 \\
Metatarsus & 6.7 & 7.0 & 9.2 & 10.5 & - \\
Tarsus & 5.0 & 4.8 & 5.8 & 6.3 & 1.3 \\
Total & 27.1 & 26.8 & 29.3 & 32.6 & 8.2 \\
\hline
\end{tabular}

2 P, 1-1-1-1-1-2 R, 1-1-2-2-2 V, tarsus $1 \mathrm{D}, 1-1-1 \mathrm{P}$. Pseudopreening combs absent. Tarsi I-IV flexible. Scopulae on tarsi I-II full and entire, III fully scopulated divided by one line of setae, IV fully scopulated divided by a row of two long setae. Scopulae entire on metatarsus I, divided by one line of setae on II-IV. Metatarsus I scopulated on $1 / 3$, II on $1 / 4$, III on $1 / 5$, IV on $1 / 4$. Superior tarsal claws with two rows of 10 to 11 teeth on each row on all tarsi. Third claw absent on all tarsi. Four spinnerets, PLS three-segmented: basal, median, and apical (digitiform short) segments $0.5,0.3$, and 0.2 long, respectively. Cymbium with thickened setae, apically directed (Figure 8D). Palp with coniform bulb gradually tapering to form a short embolus and with three high keels, almost with a vertical position (Figure 8A,B,C).

Female

Unknown.

Other materials examined Argentina, Mendoza, Malargüe department, Cerro Nevado, 3536 '47.58 "S, 68 31'39.6" W, 2,605 m.a.s.l., 15/24 February 2005, G. Debandi \& R. Carrara legs., $2 \hat{\jmath}$ (CAI 3331, 3332). Malargüe, Cerro Nevado, 35 37'43.56"S, 68³2'56.82"W, 2,333 m.a.s.l., 8/17 February 2005, G. Debandi \& E. Ruiz Manzanos legs., $2 \hat{\jmath}$ (CAI 3338, 3349). Malargüe, Cerro Nevado, cima, 35³5'45.6"S, 68³0'24.2"W, 3,130 m.a.s.l., 23/25 February 2006, M. Tognelli \& R. Carrara legs., $3 \AA$ (CAI 3292, 3293, 3296). Malargüe department, Cerro Nevado, 35³6'11.4"'S, 68³0'48.96"W, 2,908 m.a.s.l., 4/14 December 2004, G. Debandi \& G. Flores legs., 1 juvenile (CAI 3353) (Figure 6A,B,C).

Distribution and ecological notes Known only from the Cerro Nevado, Malargüe department, Mendoza (Figure 4). This species is known only from high-altitude habitats on the Cerro Nevado, an extra-Andean mountainous range located $200 \mathrm{~km}$ east of the Andes. The Nevado Range is separated from the Andean Range by a plateau of 1,800 m.a.s.l. It extends north-south between $34^{\circ}$ and $36^{\circ} \mathrm{S}$, parallel to the Andes, with a maximum altitude of 3,833 m.a.s.l (summit of Cerro Nevado). In the lower part of this range, the vegetation is a shrub steppe of Neosparton aphyllum and Sporobolus rigens on sandy and basaltic soils. All specimens were captured with pitfall traps at altitudes above 2,300 m.a.s.l. where the characteristic low vegetation has Panthacantha ameghinoi as a dominant species (Flores and Carrara 2006). Most of the individuals sampled corresponded to adult males and were caught in late summer (between 17 February 2005 and 24 February 2005; between 17 February 2006 and 25 February 2006).

\section{L. epipiptus (Zapfe, 1963)}

Diagnosis This species differs from L. longipes by its narrower sternum and lighter color (Figure 7E,F); the male palpal bulb has a long embolus with only three low keels (Figure 7A,B,C). Moreover, the male bulb embolus is shorter and distinguishes it from all Chilean species, except from L. caldera (which differs in the darker color and in having the cymbial setae directed backward; those setae are directed towards the apex in L. epipiptus). Cephalothorax, legs, and palpi yellowish brown, abdomen dark with clear-cut chevron (Figure 7D,G).

New records and distribution Known from Regions IV and V of Chile. New records for Argentina in Mendoza: Malargüe and San Carlos departments (Figure 4).

Material examined Argentina, Mendoza, Malargüe department, Cerro Nevado, 35³7'47"S, 68 32'15.42" W, 2,353 m.a.s.l., 13/20 February 2006, M. Tognelli \& R. Carrara legs., $1 \delta^{\top}$ (CAI 3277). Cerro Nevado, 35 37' 43.56"S, 68³2'56.82"W, 2,333 m.a.s.l., 8/17 February 2005, G. Debandi \& E. Ruiz Manzanos legs., $3{ }^{\lambda}$ (CAI $3335,3336,3337)$. Cerro Nevado, 353' $47.58^{\prime \prime}$ S, 68 $31^{\prime}$ 39.6"W, 2,605 m.a.s.l., 15/24 February 2005, G. Debandi $\&$ R. Carrara legs., $1{ }^{\Uparrow}$ (CAI 3333). Cerro Nevado, 35 36' 47.58"S, 68³1'39.6"W, 2,610 m.a.s.l., 8/17 February 2006, G. Debandi \& E. Ruiz Manzanos legs., $2 \delta^{\wedge}$ (CAI 3323, 3324). Cerro Nevado, cima, 35 35'45.06" S, 68 $30^{\circ}$ 24.12"W, 3,130 m.a.s.l., 23/25 February 2006, M. Tognelli \& R. Carrara legs., $2 \widehat{\jmath}$ (CAI 3297, 3276). San Carlos department, Reserva 'Laguna del Diamante', 34 14'6.17"S, $69^{\circ} 22^{\prime} 4.9^{\prime \prime} \mathrm{W}, 8 / 17$ February 2005, G. Debandi \& S. Claver legs., 7ð (CAI 3318, 3294, 3295, 3291, 3307, 3302, 3303). Reserva 'Laguna del Diamante', Alvarado, 34⒈' $6.17^{\prime \prime} \mathrm{S}$, 69²2'4.9"W, 2,347 m.a.s.l., 13/23 February 2006, S. Claver \& R. Carrara legs., $2 \hat{\jmath}$ (CAI 3328, 3329). Reserva 'Laguna del Diamante', Alvarado, 34 $14^{\prime} 47.4^{\prime \prime} \mathrm{S}, 69^{\circ} 22^{\prime}$ 58.2"W, 2,358 m.a.s.l., 23/25 February 2006, S. Roig \& G. Debandi legs., 1ð (CAI 3305). Reserva 'Laguna del Diamante', Alvarado, 3414' 46.9' S, 69²2'40.3"W, 2,310 m. a.s.l., 5/8 January 2006, S. Roig \& G. Debandi legs., $1 \delta$ (CAI 3301). Chile, Región V (Valparaíso), Quebrada El Tigre, Cachagua, November 1988, P. Goloboff, E. Maury \& C. Szumik legs., 1 ㅇ (MACN-Ar), pictures examined. 


\section{L. longipes Thorell, 1894}

Diagnosis This species differs from the Chilean species of Lycinus by the wider sternum (Figure 9F); the male palpal tibia long and cymbium with apically directed setae (Figure 9D), bulb tapering gradually, with short embolus and three very high diagonal keels (Figure 9A, B,C). Entire spiders uniformly dark black (Figures 9E,F,G and 10B).

Material examined Argentina, Mendoza, Las Heras department, Estancia Tambillos, 32 $22^{\prime} 7.56^{\prime \prime} \mathrm{S}, 6^{\circ} 26^{\prime} 3.26^{\prime \prime}$ W, 2,390 m.a.s.l., 4/14 December 2004, A. Scollo \& S. Claver legs., $1 \widehat{\jmath}$ (CAI 3334). Same locality, 32 $21^{\prime} 14.88^{\prime \prime}$ S, 69²5'52.38"W, 2,428 m.a.s.l., 20 December 2005/5 January 2006, S. Claver \& A. Scollo legs., $2 \hat{\jmath}$ (CAI 3325, 3326). Ruta prov. 52, 32³7'10.56"S, 68 54'49.02"W, 978 m.a.s.l., 4/14 December 2004, S. Claver \& A. Scollo legs., $1 \overbrace{}^{\lambda}$ (CAI 3327). Capital department, Reserva Natural Divisadero Largo, 3252'48.8"S, 6856'02.3"W, 1,474 m.a.s.l., 17 February 2013, N. Ferretti leg., 2 (CAI 3497, 3498).

Distribution and ecological notes Previously known from Santiago del Estero, Salta, Córdoba, La Rioja, Neuquén, Catamarca, San Juan (Figure 11). In Mendoza, a single female (not examined) was recorded in Nacuñan by
Goloboff (1995). However, a recent campaign (involving day and night collections) on this Natural Reserve yielded only specimens of $L$. lagigliai $\mathrm{sp}$. nov. There are new records of L. longipes for Mendoza in Las Heras and Capital departments (Figure 11). The only available information came from specimens collected in salt flats and in depressed, floodable areas, in which spiders live in deep burrows (up to $40 \mathrm{~cm}$ deep), about $20 \mathrm{~mm}$ wide, with smooth well-compacted and cemented walls, lined with a thin layer of silk. The burrows are closed by means of a door, without hinge, which lies over the burrow mouth (Goloboff 1995). I found specimens of L. longipes inhabiting non-flooding areas, comprising the Andean foothills at an elevation of about 1,500 m.a.s.l. (Figure 10A). Spiders captured at Divisadero Largo Natural Reserve were active at night, and open burrows (Figure 10C) are similar to those described by Goloboff (1995). One adult female (Figure 10B) was found walking; its burrow could not be located.

\section{Biogeography}

According to the RASP optimization, one tree of possible ancestral distributions was obtained (Figure 12A). The ancestral areas reconstructed at the root of the genera Lycinus and Chilelopsis are most likely to be either Coquimbo (Andean region) or both Coquimbo and Monte (South American Transition Zone). A vicariant

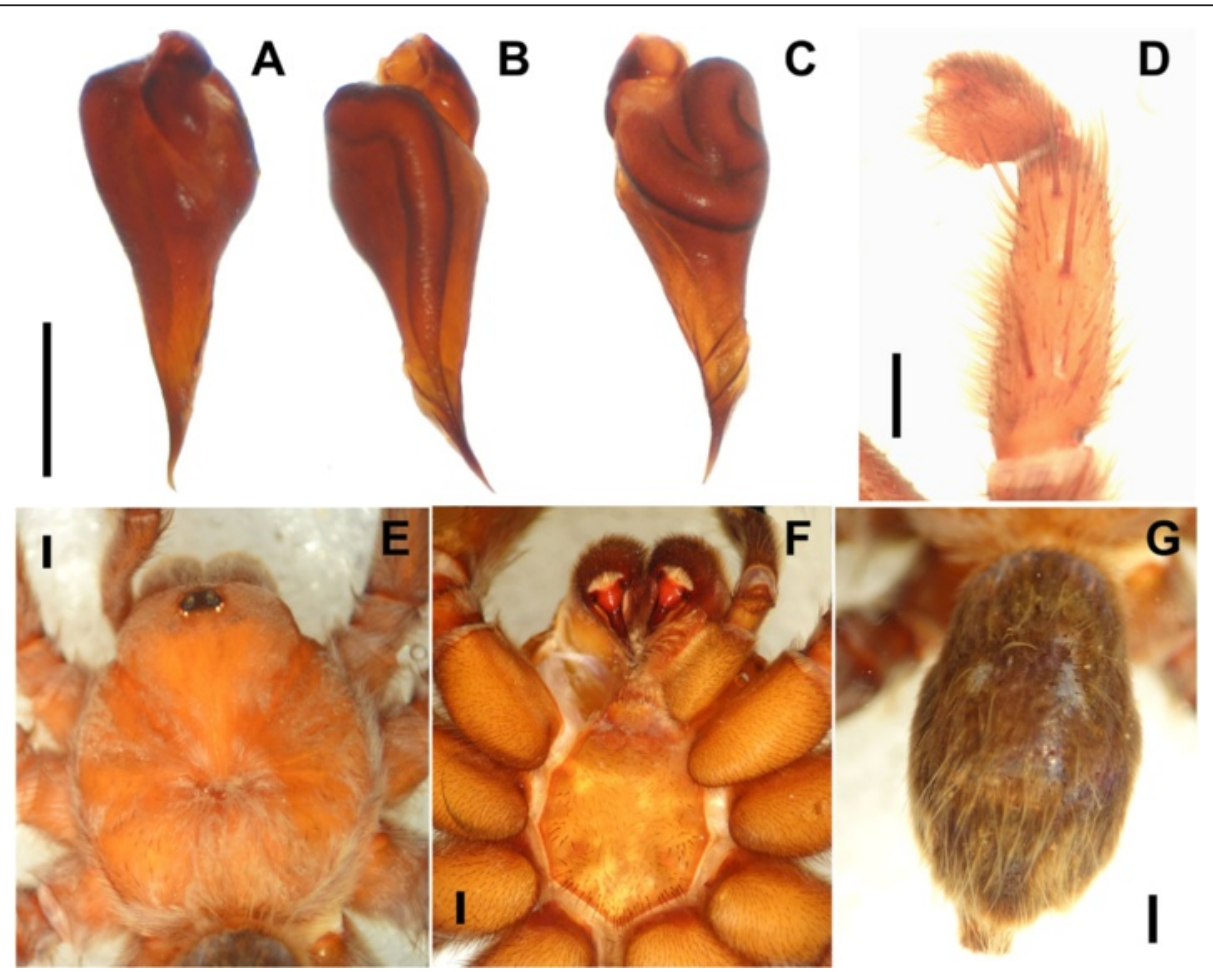

Figure 9 Lycinus longipes, male (CAI 3334). (A-C) Left palpal bulb: (A) prolateral, (B) ventral, (C) retrolateral. (D) Palpal tibia, retrolateral view. (E) Carapace, dorsal view. (F) Sternum, ventral view. (G) Abdomen, dorsal view. Scale bars $=1 \mathrm{~mm}$. 


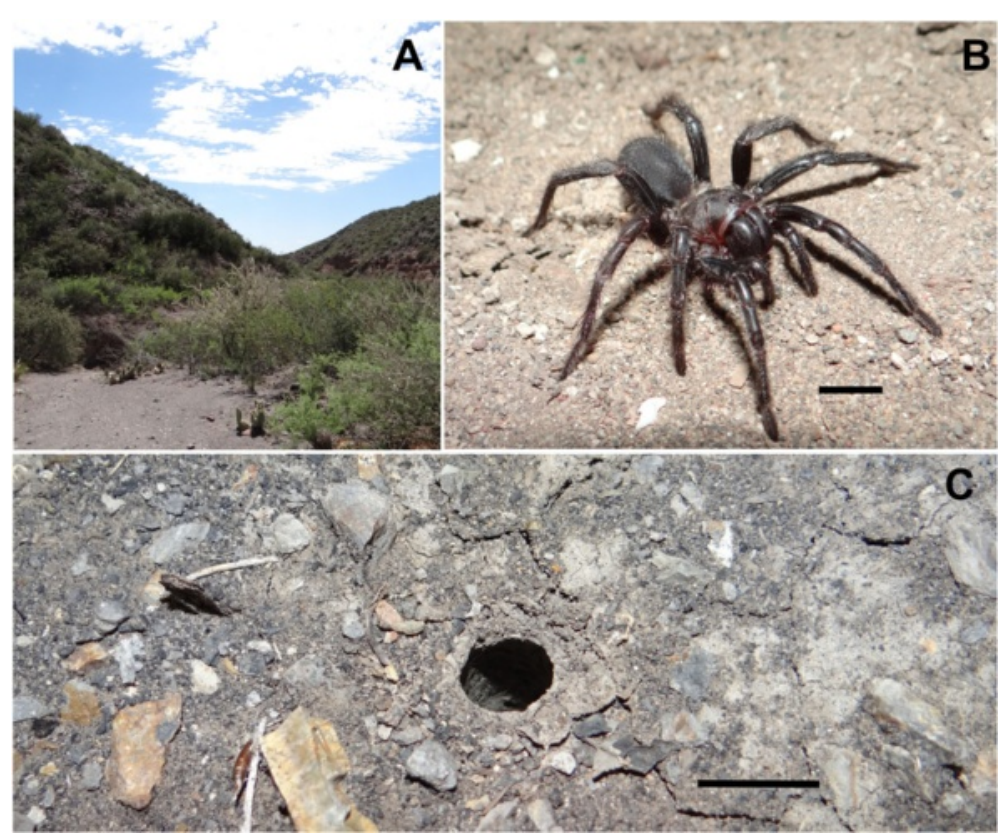

Figure 10 Natural history of L. longipes. (A) Habitat characteristics where the species occur. (B) Female, live habitus. (C) Female burrow opened at night. Scale bar $=1 \mathrm{~cm}$.

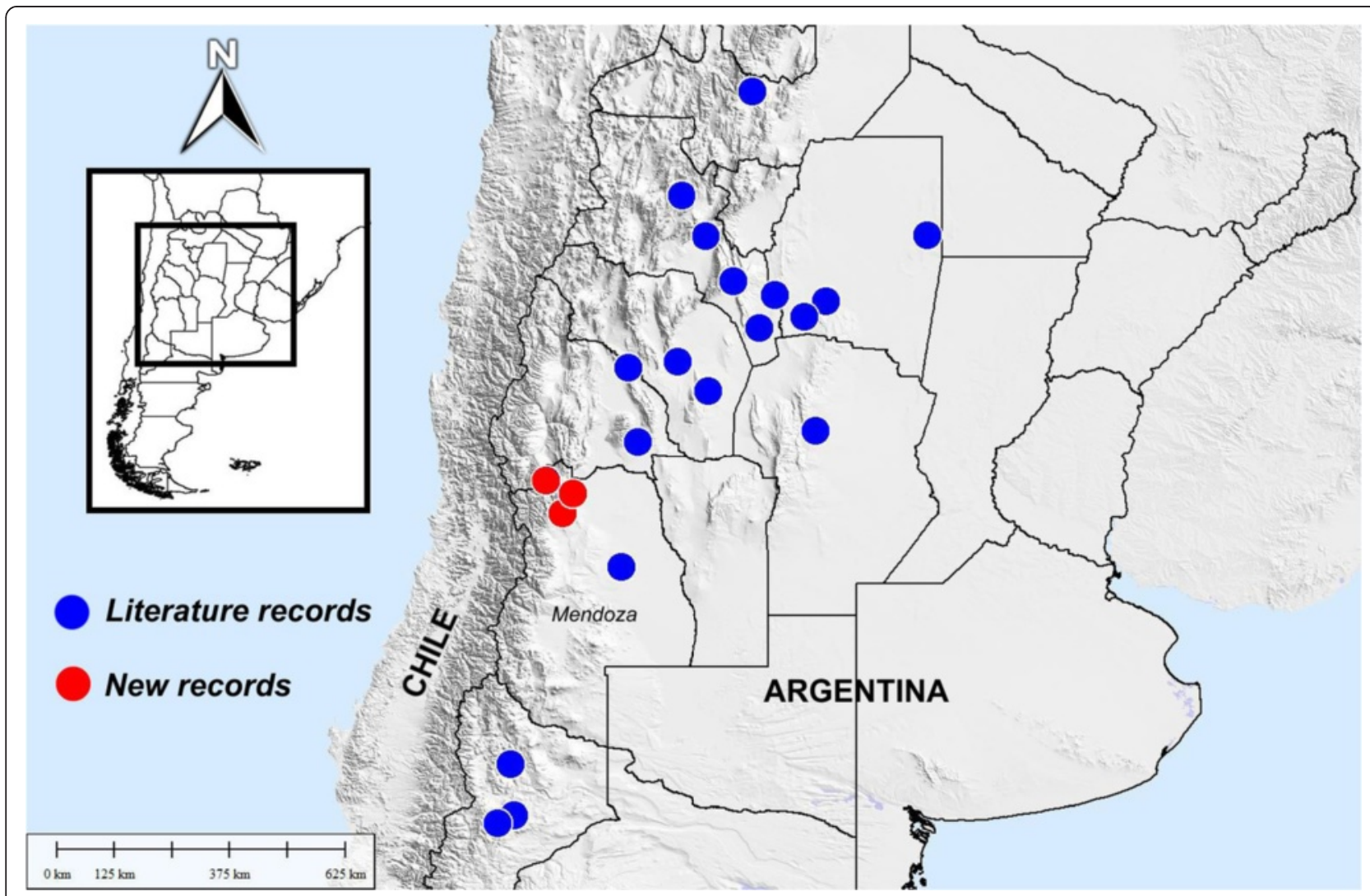

Figure 11 Map of western Argentina showing the known distribution of L. longipes. 


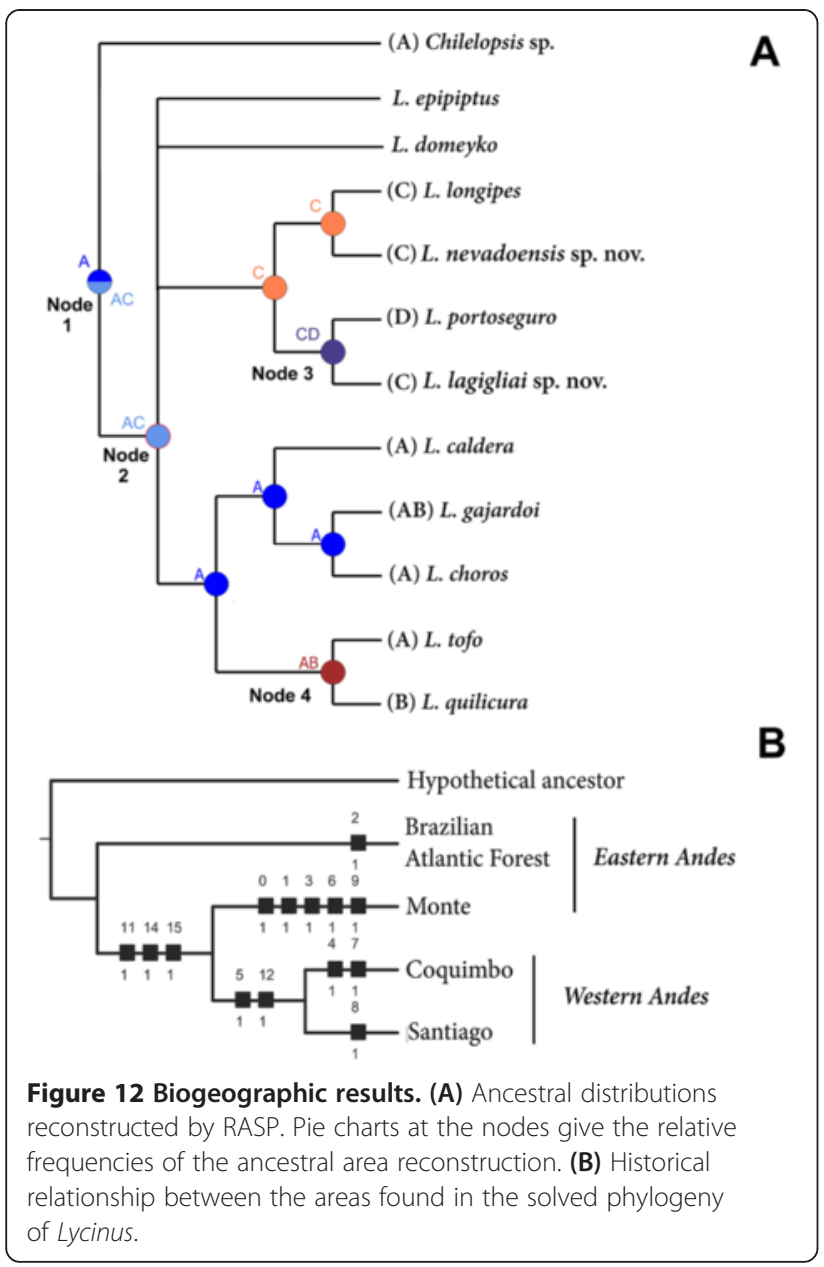

event (node 1, Figure 12A) took place, resulting in two isolated groups: Chilelopsis (Coquimbo) and Lycinus (Coquimbo-Santiago-Monte-Brazilian Atlantic Forest). Subsequently, a second vicariant event (node 2, Figure 12A) separated the Argentinean-Brazilian species L. longipes, L. nevadoensis sp. nov., L. portoseguro, and L. lagigliai sp. nov. in Monte and Brazilian Atlantic Forest provinces from the clade containing the Chilean species $L$. caldera, L. gajardoi, L. choros, L. tofo, and L. quilicura in Coquimbo and Santiago provinces, with possible ancestral areas of the Coquimbo-Monte. Then, a new vicariant event (node 3, Figure 12A) separated L. lagigliai sp. nov. in the Monte from $L$. portoseguro in the Brazilian Atlantic Forest, with the possible ancestor located at the Monte. Finally, a new vicariant event (node 4, Figure 12A) separated $L$. tofo in the Coquimbo region from $L$. quilicura in the Santiago region. The possible ancestral areas for this node were the Coquimbo-Santiago. The primary BPA resulted in a single cladogram of length 19, with a consistency index of 0.89 and a retention index of 0.71 (Figure 12B).

According to the area cladogram obtained through BPA and based on the assumption of a vicariance model, the monophyly of areas at western and eastern of the Andes, such as Coquimbo, Santiago, and Monte, showed the close relationship between the fauna of the Andean region with that of the South American Transition Zone. From the results of RASP, the second ancestral distribution resulting from the analysis showed Lycinus inhabiting the areas today occupied by the Coquimbo (Andean region) and Monte (South American Transition Zone). The association of these two areas has been proposed by Morrone (2006) with examples of many species of Orthoptera, Coleoptera, Diptera, Hymenoptera, and Lepidoptera that are common to the Andean region and the South American Transition Zone. Moreover, most of the Andean biota originally evolved in Patagonia and then gradually spread northward into the South American Transition Zone during the Tertiary and Pleistocene (Morrone 1994). The events that influenced the separation of the Argentinean-Brazilian species from the Chilean could take place from the late Oligocene to the late Miocene. During this period, the present morphostructural configuration of the Andes of Central Chile began to develop (Donato et al. 2003). The southern South America landscapes began to be dominated by the processes that led to the present configuration of the Andean tectonic-magmatic belt (Uliana and Biddle 1988). Also, three successive Atlantic marine transgressions were recorded in southern South America. Therefore, during the middle and late Miocene, an open seaway separated the terrestrial environments of southern South America from those farther north, spreading over virtually all of eastern Argentina, western Uruguay, southern Paraguay, and southeastern Bolivia (Pascual et al. 1996; Donato et al. 2003). Finally, the events related to the split of L. lagigliai sp. nov. (Monte) from L. portoseguro (Brazilian Atlantic Forest) that could have been influenced during the late Miocene-late Pliocene span comprehend a new Andean diastrophic phase, named 'Diaguita phase' (Pascual et al. 1996; Donato et al. 2003) that resulted in the elevation of the Central Cordillera of Argentina and Chile, the eastern orographic systems of Argentina, and the uplift of the Mesopotamian region. This event led to the end of the Age of the Southern Plains that corresponded to widespread and varied plains, extending from northern Patagonia, reaching central and northern Argentina, Uruguay, the eastern slopes of the rising Andes in Bolivia, Peru, and Venezuela, and also in the Amazon basin (Marshall et al. 1983; Pascual et al. 1996) involving the ancestral areas of L. lagigliai sp. nov. and $L$. portoseguro.

The species $L$. nevadoensis sp. nov. described in this study could be another representative of the endemic fauna of El Nevado mountain chain. This orographic system comprises a relevant area of endemism for highaltitude arthropod fauna, with closely related species found at high-altitude locations in the Andean range. 
This feature could be due to the high distance that separates it from the Andean mountain chain $(200 \mathrm{~km})$. Some of the endemic taxa described for the Nevado mainly include carabid beetles, such as Cnemalobus nevado Roig-Juñent et al., 2007, Baripus nevado RoigJuñent et al., 2008, and Trechisibus nevadoi Roig-Juñent and Sallenave 2005, but recently, the scorpion Orobothriurus grismadoi Ojanguren-Affilastro et al., 2009 has been described as endemic for this mountain range (Ojanguren-Affilastro et al. 2009). As mentioned, it has been found that some of the sister species of these endemic taxa occurs in high-altitude locations in the Andean range (for example, Laguna del Diamante, Mendoza) (Roig-Juñent et al. 2007). This could be the case for L. epipiptus in Argentina, whose distribution corresponds to El Nevado range, and also at high Andean altitudes such as Laguna del Diamante, but unfortunately, the position of this species in the cladogram was not solved. The accumulation of diversity studies involving species that occur at the Andean mountains will shed light on the biogeographical hypotheses in relation to this relevant region.

\section{Conclusions}

Two new species are recognized in Lycinus and are diagnosed and described. According to the cladistic reanalysis, the main relationships found and the characters supporting are the same as those found by Goloboff (1995). Some events that could have influenced in the distributional patterns of the species of Lycinus comprised the following: i) the processes that led to the present formation of the Andean tectonic-magmatic belt, ii) three successive Atlantic marine transgressions that were recorded in southern South America, and iii) a new Andean diastrophic phase, named 'Diaguita phase', that resulted in the elevation of the Central Cordillera of Argentina and Chile, the eastern orographic systems of Argentina, and the uplift of the Mesopotamian region.

\section{Abbreviations \\ AME: anterior median eyes; ALE: anterior lateral eyes; D: dorsal; P: prolateral, PLE: posterior lateral eyes; PLS: posterior lateral spinnerets; PME: posterior} median eyes; R: retrolateral; V: ventral.

\section{Competing interests}

The author declares that he has no competing interests.

\section{Author's information}

NF is a researcher of the National Council of Scientific and Technical Research (CONICET) in Argentina. His research interest focuses on the systematics, biogeography, ecology, and ethology of mygalmorph spiders.

\section{Acknowledgements}

Thanks to Susana Lagos Silnik for loaning the collection material from IADIZA. The author thanks Cristian Grismado for supplying some images from MACN-Ar specimens. Thanks to Gabriel Pompozzi, Sofía Copperi, and Leonela Schwerdt for their help on field trips and photographs. Thanks to Alda González for her constant support on research experience. This work was partially funded by the American Arachnological Society and Vincent
Roth Foundation to the project 'Diversity of mygalomorph spiders (Araneae) in Mendoza province, Argentina: How many species are there?' Special thanks to the park rangers from Ñacuñan and Divisadero Largo natural reserves for their help during field work. Thanks to the Instituto Argentino de Investigaciones de las Zonas Áridas (IADIZA), CCT-CONICET Mendoza, and the Dirección de Recursos Naturales Renovables, Mendoza for the collection permits. The author is a researcher of Consejo Nacional de Investigaciones Científicas y Técnicas (CONICET).

Received: 18 August 2014 Accepted: 10 December 2014

Published online: 13 January 2015

\section{References}

Antonelli A, Verola CF, Parisod D, Gustaffson ALF (2010) Climate cooling promoted the expansion and radiation of a threatened group of South American orchids (Epidendroideae: Laeliinae). Biol J Linn Soc 100:597-607

Brooks DR, Van Veller M, MacLennan DA (2001) How to do BPA, really. J Biogeog 28:343-358

Capocasale MR, Pérez-Miles F (1990) Behavioural ecology of Acanthogonatus tacuariensis (Pérez \& Capocasale) (Araneae, Nemesiidae). Stud Neotrop Fauna Environ 25:41-47

Crisci JV, Katinas L, Posadas P (2003) Historical biogeography: an introduction. Harvard University Press, Cambridge

Donato M (2006) Historical biogeography of the family Tristiridae (Orthoptera: Acridomorpha) applying dispersal vicariance analysis. J Arid Environ 66:421-434

Donato M, Posadas P, Miranda-Esquivel DR, Ortiz-Jaurequizar E, Cladera G (2003) Historical biogeography of the Andean region: evidence from Listroderina (Coleoptera: Curculionidae: Rhytirrhinini) in the context of the South American geobiotic scenario. Biol J Linn Soc 80:339-352

Ferretti N, Pompozzi G, Pérez-Miles F (2011) Sexual behavior of Acanthogonatus centralis (Araneae: Mygalomorphae: Nemesiidae) from Argentina, with some notes on their burrows. J Arachnol 39:533-536

Ferretti N, González A, Pérez-Miles F (2012) Historical biogeography of the genus Cyriocosmus (Araneae: Theraphosidae) in the Neotropics according to an event-based method and spatial analysis of vicariance. Zool Stud 51:526-535

Flores G, Carrara R (2006) Two new species of Nyctelia Latrielle, from western Argentina with zoogeographical and ecological remarks on the high mountain habitat (Coleoptera: Tenebrionidae). Ann Zool 56:487-495

Goloboff PA (1993) Estimating characters weights during tree search. Cladistics 9:83-91

Goloboff PA (1995) A revision of the South American spiders of the family Nemesiidae (Araneae, Mygalomorphae). Part I: species from Peru, Chile, Argentina, and Uruguay. Bull Am Mus Nat Hist 224:1-189

Goloboff P, Farris J, Nixon K (2003) T.N.T.: tree analysis using new technology, program and documentation. http://www.lillo.org.ar/phylogeny/. Accessed 2 Apr 2012

Guo Y, Wang Y (2007) Partitioned Bayesian analyses, dispersal-vicariance analysis, and the biogeography of Chinese toad-headed lizards (Agamidae: Phrynocephalus): a re-evaluation. Mol Phylogen Evol 45:643-662

Indicatti RP, Lucas SM (2005) Description of a new genus of Nemesiidae (Araneae, Mygalomorphae) from Brazilian Cerrado. Zootaxa 1088:11-16

Indicatti RP, Lucas SM, Ott R, Brescovit AD (2008) Litter dwelling mygalomorph spiders (Araneae: Microstigmatidae, Nemesiidae) from Araucaria forests in southern Brazil, with the description of five new species. Rev Bras Zool 25:529-546

Lucas SM, Indicatti RP (2010) Description of two new species of Lycinus (Araneae: Nemesiidae). Zoologia 27:425-430

Lucas SM, Passanha V, Janini CRV, Indicatti RP (2008) On the genus Neostothis Vellard (Araneae, Nemesiidae). J Arachnol 36:472-475

Marshall LG, Hoffstetter R, Pascual R (1983) Mammals and stratigraphy: geochronology of the continental mammal-bearing Tertiary of South America. Paleovertebrata: Mémoire Extraordinaire 1983:1-93

Montes de Oca L, Pérez-Miles F (2013) Two new species of Chaco Tullgren from the Atlantic coast of Uruguay (Araneae, Mygalomorphae, Nemesiidae). Zookeys 377:73-87

Morrone JJ (1994) Distributional patterns of species of Rhytirrhinini (Coleoptera: Curculionidae) and the historical relationships of the Andean provinces. Global Ecol Biogeogr Lett 4:188-194

Morrone JJ (2006) Biogeographic areas and transition zones of Latin America and the Caribbean islands based on panbiogeographic and cladistic analyses of the entomofauna. Annu Rev Entomol 51:467-494 
Morrone JJ (2014) Biogeographical regionalisation of the Neotropical región. Zootaxa 3782:1-110

Ojanguren-Affilastro AA, Fernández Campón F, Lagos Silnik S, Mattoni Cl (2009) The genus Orobothriurus Maury in central Argentina with description of a new species from El Nevado mountain chain in Mendoza Province (Scorpiones: Bothriuridae). Zootaxa 2209:28-42

Ojeda RA, Campos CM, Gonnet JM, Borghi CE, Roig VG (1998) The MaB Reserve of Nacuñán, Argentina: its role in understanding the Monte Desert biome. J Arid Environ 39:299-313

Page RDM (2001) NDE, Nexus Data Editor, ver 0.5.0. http://taxonomy.zoology.gla. ac.uk/rod/NDE/nde.html. Accessed 25 June 2010

Pascual R, Ortiz-Jaureguizar E, Prado JL (1996) Land mammals: paradigm of Cenozoic South American geobiotic evolution. Münchner Geowiss Abh 30:265-319

Petrunkevitch A (1925) Arachnida from Panama. Trans Conn Acad Arts Sci 27:51-248

Platnick, NI (2014) The world spider catalog, version 14.5. American Museum of Natural History. http://www.wsc.nmbe.ch/. Accessed 14 May 2014

Raven RJ (1985) The spider infraorder Mygalomorphae (Araneae): cladistics and systematics. Bull Am Mus Nat Hist 182:1-180

Roig-Juñent S, Carrara R, Ruiz-Manzanos E, Agrain F, Sackmann P, Tognelli FM (2007) Phylogenetic relationships and biogeographic considerations of four species of Cnemabolus (Coleoptera, Carabidae) from Patagonia. Insect Syst Evol 38:1-26

Simon E (1889) Voyage de M.E. Simon au Venezuela, Arachnides. Ann Soc Entomol Fr 6:169-220

Thorell T (1894) Decas aranearum in ins. Singapore a Cel. Th. Workman inventarum. Boll Soc Entomol Ital 26:321-355

Uliana MA, Biddle KT (1988) Mesozoic-Cenozoic paleogeographic and geodynamic evolution of southern South America. Braz J Geol 18:172-190

Yu Y, Harris AJ, He X (2010) S-DIVA (Statistical Dispersal-Vicariance Analysis): a tool for inferring biogeographic histories. Mol Phylogen Evol 56:848-850

\section{Submit your manuscript to a SpringerOpen ${ }^{\circ}$ journal and benefit from:}

- Convenient online submission

- Rigorous peer review

- Immediate publication on acceptance

- Open access: articles freely available online

- High visibility within the field

- Retaining the copyright to your article

Submit your next manuscript at $>$ springeropen.com 